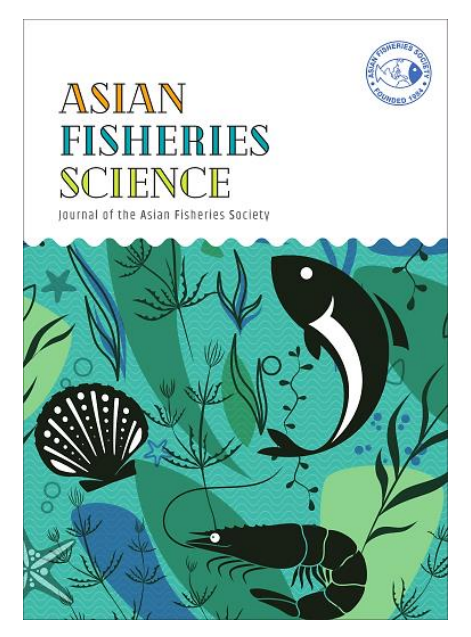

\title{
Population Dynamics of Nile Tilapia, Oreochromis niloticus (Linnaeus, 1758)(Teleostei, Cichlidae), in Some Irrigation Reservoirs of Sri Lanka
}

\author{
K.V. SANDUN N. BANDARA ${ }^{1}$, P.A.D. AJITH KUMARA ${ }^{2}$, UPALI S. AMARASINGHE ${ }^{1, *}$ \\ 'Department of Zoology and Environmental Management, University of Kelaniya, Kelaniya 11600, Sri Lanka \\ ${ }^{2}$ National Aquatic Resources Research \& Development Agency, Colombo 15, Sri Lanka \\ *E-mail: zoousa@kln.ac.lk | Received: 28/01/2020; Accepted: 20/06/2020
}

(C)Asian Fisheries Society

ISSN: 0116-6514

E-ISSN: 2073-3720

https://doi.org/10.33997/j.afs.2020.33.2.010

\section{Abstract}

Oreochromis niloticus (Linnaeus, 1758) exhibits differences in demographic parameters across the reservoirs, resulting in inconsistencies in optimal fishing strategies. This study aimed at investigating 0 . niloticus populations in 10 reservoirs. Length-frequency data of 0 . niloticus from fish landings of 10 irrigation reservoirs in Sri Lanka were corrected for multi-mesh gillnet selection and were analysed by FiSAT II stock assessment software. Asymptotic total length ranged from $42.8 \mathrm{~cm}$ to $53.4 \mathrm{~cm}$ and growth constant ranged from $0.20 \mathrm{yr}^{-1}$ to $0.49 \mathrm{yr}^{-1}$. As growth performance indices of 10 reservoir populations of 0 . niloticus were within the range reported previously and as the estimated growth parameters fall within the "growth space" of the species, these estimates were consistent with those reported in the literature. Length-converted catch curves of 10 reservoir populations of 0 . niloticus also gave reliable estimates of total mortality. Exploitation rates of the 10 populations ranged from very low (0.14) to very high (0.76) values. From the relative yield-per-recruit analyses, it was apparent that in some reservoirs, long-term fish yields can be optimised using gillnet mesh sizes of $7.6 \mathrm{~cm}$. While optimal long-term fish yields of 0 . niloticus in other reservoirs could be achieved by increasing the permissible gillnet mesh size above the legal mesh size of $8.4 \mathrm{~cm}$. Hence, the gillnet mesh regulations in the Sri Lankan reservoir fishery should not be uniform but reservoir-specific. Accordingly, site-specific management options, which are defined in consultation of resource users are necessary to be implemented in reservoir fisheries of the country.

Keywords: Cichlidae, fishbase, inland fisheries, tropical reservoirs, von Bertalanffy growth

\section{Introduction}

Tilapiine fishes, native to the African continent and Jordan valley have been introduced throughout the world for various purposes such as to facilitate aquaculture development and to enhance inland fisheries (Beveridge and McAndrew, 2000; CostaPierce, 2003; De Silva et al., 2004; Canonico et al., 2005; Hishamunda et al., 2009). According to Database on Introductions of Aquatic Species (DIAS) (http://www.fao.org/fishery/dias/en), there are 116 records of introduction of the cichlid species, Oreochromis niloticus (Linnaeus, 1758) mainly for the development of aquaculture. A comprehensive review on the role of exotic tilapias in the Asia-Pacific region (De Silva et al., 2004) has shown that this group of fish has made a significant contribution to food supply, poverty alleviation and livelihood support in many Asian countries. There is however, scant explicit evidence to indicate that tilapias have been overly destructive environmentally.

Tilapias in the genus Oreochromis are adapted to feeding on and digestion of phytoplankton and other microorganisms that add omega 3 fatty acids, and make wild populations much healthier to consume, the characteristics that made a positive prognosis to label them as 'aquatic chicken' (Perschbacher, 2014). On the other hand, bioaccumulation of heavy metals in 0 . niloticus was reported in fish farms and feral populations of polluted aquatic environments (Omar et al., 2013; El-Batrawy et al., 2018). 
In Sri Lanka, inland fishery is essentially dependent on the multitude of reservoirs, which has been relatively a recent development during the second half of the twentieth century making a significant impact on the rural economy as a source of affordable source of animal protein for rural communities (De Silva, 1988; Amarasinghe and Weerakoon, 2009). The exotic cichlid, 0. niloticus is ubiquitous in reservoirs of Sri Lanka, and has a very high consumer acceptance. In the inland fishery of Sri Lanka, O. niloticus accounted for about $61.2 \%$ of the total annual landings of 81,870 in 2017 (Ministry of Fisheries and Aquatic Resources Development, 2018) supporting livelihoods of about 37,000 inland fishers. In the reservoir fishery of the country, fishing craft is non-mechanised fibre-glass out-rigger canoe and the major fishing gear is gillnet. Two fishers working on each canoe set gillnets (approximately $300 \mathrm{~m}$ in length) during dusk that are hauled at dawn on the following day. Inland fisheries regulations imposed by the fisheries authorities (Anon., 1996) are aimed at managing the cichlid fishery. Accordingly, mechanisation of fishing boats and use of any encircling fishing gear are not permitted. The minimum permissible mesh size of gillnet is $8.5 \mathrm{~cm}$ stretched mesh size.

Oreochromis niloticus has ability and adaptability of spawn in any lentic environment in lake and reservoirs in many tropical regions of the world (Blanco et al., 2007; Schofield et al., 2011). Also, the adverse impacts of 0 . niloticus on native fish species and aquatic biodiversity have been reported. For example, significant reduction in the capture of several indigenous fish species was evident in the fishery of a tropical reservoir in north-eastern Brazil that may have been caused, at least partially, by the introduction of 0 . niloticus (Attayde et al., 2011). Through a controlled experiment in earthen ponds, significant interspecies dietary overlap was found between 0 . niloticus and small indigenous fish species in Bangladesh (Ahmad et al., 2010).

Scientific information about 0 . niloticus is rich. According to Fishbase (Froese and Pauly, 2019), 0. niloticus is reported to occur in 104 countries in Africa, Asia, Europe, North America, South America and Oceania, and 585 references are listed on various aspects of aquaculture and fisheries.

Previous studies on population dynamics of 0 . niloticus populations in Sri Lankan reservoirs indicated that there were substantial differences in growth and mortality parameters across the reservoirs, which have resulted in inconsistencies in optimal fishing strategies (Amarasinghe and De Silva, 1992; Amarasinghe, 2002; Athukorala and Amarasinghe, 2010; Amarasinghe et al., 2017). As inland fisheries regulations common to the entire country that have been formulated by centralised management establishments, without considering spatial variations of life history strategies, their overall effectiveness for the management of reservoir fisheries is questionable.
These evidence lead authors to postulate the hypothesis that there are remarkable differences in demographic characteristics of 0 . niloticus between irrigation reservoirs that are likely to be under the stress of various environmental perturbation.

Many studies on the population dynamics of 0 . niloticus (e.g., Kolding, 1993; Assefa et al., 2019) that have been reported generally dealt with life-history traits and exploitation patterns. Abobi et al. (2019) analysed length-frequency data of three cichlid species including 0 . niloticus in the small-scale fisheries of the Tono, Bontanga, and Golinga reservoirs in northern Ghana, to determine growth, mortality, exploitation status, stock size, and relative yield per recruit reference points using bootstrapping fish stock assessment. This is a novel framework that allows for the estimation of uncertainties around the life-history parameters and reference levels. It is also a fact that possible variation of demographic parameters of fish populations over time (Brown et al., 2019) might have implications on the optimal fishing strategies. Therefore, investigation of population dynamics of 0 . niloticus in lakes and reservoirs in relation to fisheries regulations is important for sound scientific management of the fisheries. In light of this, the present study was aimed at investigating population dynamics of 10 reservoir populations of 0 . niloticus in the Kala Oya river basin of Sri Lanka to understand the effectiveness of existing inland fisheries regulations for their management. The reservoirs selected for the current study were Angamuwa, Balaluwewa, Dewahuwa, Ibbankatuwa, Kandalama, Katiyawa, Kalawewa, Rajanganaya, Siyambalangamuwa and Usgala Siyambalangamuwa.

\section{Materials and Methods}

The present study was carried out in 10 irrigation reservoirs in the Kala Oya river basin of Sri Lanka (Fig. 1). Morphometric characteristics (i.e., catchment area, reservoir capacity, area and mean depth) and mean chlorophyll-a content are given in Table 1. These 10 reservoirs ranged in size from 146 ha (Siyambalangamuwa) to 1980 ha (Kalawewa) at full supply level and other morphometric and edaphic characteristics also varied over wide ranges (Table 1). Field data collection was carried out from April 2014 to April 2016 visiting each reservoir approximately once in two months. There were 10 sampling visits to Dewahuwa, Kandalama, Rajanganaya and Siyambalngamuwa, 11 visits to Ibbankatuwa and Katiyawa, 13 visits to Balaluwewa, 14 visits to Angamuwa and Kalawewa and 17 visits to Usgala Siyambalangamuwa. For ethical clearance, permission for conducting research was obtained from the University of Kelaniya, Sri Lanka.

\section{Collection of length-frequency data}

On each sampling occasion, all the fishing boats landed in a given reservoir were examined to collect 


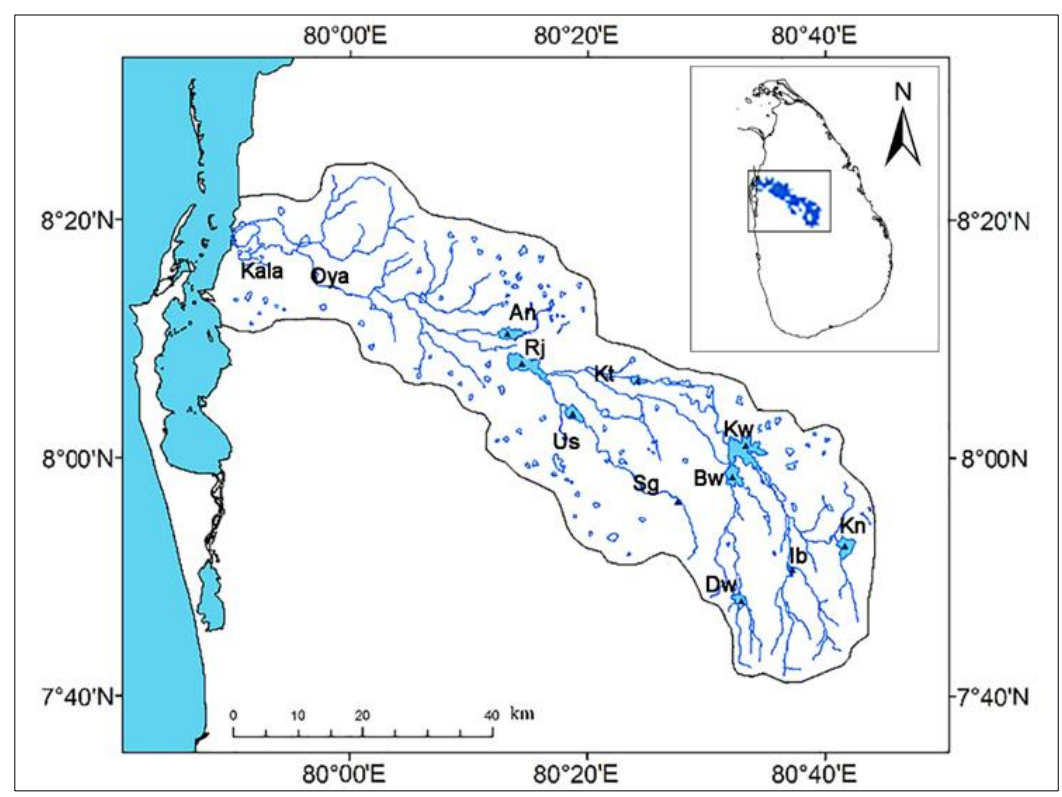

Fig. 1. Geographical locations of 10 irrigation reservoirs studied in the Kala oya river basin. Inset shows Kala oya river basin in relation to rest of Sri Lanka. An - Angamuwa, Bw - Balaluwewa, Dw - Dewahuwa, lb - Ibbankatuwa, Kn - Kandalama, Kt Katiyawa, Kw - Kalawewa, Rj - Rajanganaya, Sg - Siyambalangamuwa and Us -Usgala Siyambalangamuwa.

Table 1. Morphometric and edaphic characteristics of 10 reservoirs studied.

\begin{tabular}{llllllll}
\hline Reservoir(Abb.) & $\begin{array}{l}\text { Catchment area } \\
\left(\mathrm{km}^{2}\right)\end{array}$ & $\begin{array}{l}\text { Reservoir capacity } \\
(\text { MCM) }\end{array}$ & $\begin{array}{l}\text { Area } \\
(\mathrm{ha})\end{array}$ & $\begin{array}{l}\text { Mean depth } \\
(\mathrm{m})\end{array}$ & $\begin{array}{l}\text { HRT } \\
(\mathrm{yrs}))^{*}\end{array}$ & $\begin{array}{l}\text { RRLF* } \\
\text { Chl-a } \\
\left(\mathrm{mg} . \mathrm{m}^{-3}\right)^{*}\end{array}$ \\
\hline Angamuwa(An) & 129.5 & 15.79 & 792 & 1.99 & 0.315 & 91.89 & 17.96 \\
Balaluwewa(Bw) & 269.8 & 41.42 & 934 & 4.43 & 0.149 & 148.81 & 24.48 \\
Dewahuwa(Dw) & 67.3 & 13.56 & 433 & 3.13 & 1.476 & 207.02 & 20.58 \\
Ibbankatuwa(Ib) & 169.0 & 11.72 & 405 & 2.89 & 0.012 & 162.21 & 8.00 \\
Kandalama(Kn) & 98.0 & 33.74 & 736 & 4.58 & 0.748 & 124.85 & 25.12 \\
Katiyawa(Kt) & 86.7 & 5.55 & 257 & 2.16 & 0.388 & 104.07 & 22.43 \\
Kalawewa(Kw) & 572.0 & 87.81 & 1980 & 4.43 & 0.149 & 148.81 & 25.21 \\
Rajanganaya(Rj) & 1611.0 & 100.66 & 1599 & 6.30 & 0.448 & 51.18 & 19.80 \\
Siyambalangamuwa(Sg) & 46.6 & 2.60 & 146 & 1.78 & 0.156 & 166.16 & 8.22 \\
Usgala & 184.6 & 26.72 & 769 & 3.47 & 0.191 & 89.16 & 17.62 \\
Siyambalangamuwa(Us) & & & & & \\
\hline
\end{tabular}

Abb.: Abbreviations for reservoir names used in this study. MCM - million cubic metres; Chl-a: chlorophyll-a; Sources of data are from the Irrigation Department of Sri Lanka and the Mahaweli Authority of Sri Lanka; * Data from Nadarajah (2019). HRT: Hydraulic retention time; $R R L F\left(=\frac{Z_{\text {Max }}-Z_{\text {Min }}}{\text { Mean depth }} \times 100\right)$.

$Z_{\max }=$ maximum depth in $m_{i} Z_{\min }=$ minimum depth in $m_{;} H R T=$ Ratio of reservoir volume in million cubic metres (MCM) to annual outflow in MCM.yr-1.

mesh-wise length-frequency data (LFD) of O. niloticus. Collection of LFD was essentially performed from the commercial landings of multi-mesh gillnet fisheries in the reservoirs, during the limited period of time available between landing and selling to the fish vendors. In the instances where number of fish landed from a gillnet of a given mesh size was $<40$, total length of all specimens of 0 . niloticus was recorded. In the gillnets of mesh sizes having larger number of landed fish (>40), a sample of a minimum of 40 was randomly chosen using a two-digit random number generator to record LFD. In the gillnet fisheries of all 10 reservoirs, stretched mesh size of gillnets ranged from $6.9 \mathrm{~cm}$ to $11.4 \mathrm{~cm}$.

As LFD of the present study were corrected using the approach presented by Jayasinghe et al. (2017), the number of net pieces of each mesh size used in the sampling boats was also recorded. Total length (TL) measurements of 0 . niloticus during each field visit in each reservoir were grouped into $0.5 \mathrm{~cm}$ class intervals and latter converted into $2 \mathrm{~cm}$ length classes for improvement of goodness-of-fit of growth curves (Gulland and Rosenberg, 1992; Gayanilo et al., 2005).

\section{Correction of LFD for gillnet selection}

As composition of the mesh sizes of gillnets that fishermen carry in their boats is not consistent, the relative contribution of each mesh size to the overall selection should be incorporated in determining the total selectivity function in multi-mesh gillnet fisheries. Accordingly, all LFD were corrected for gillnet selection using length-wise probabilities of capture (Jayasinghe et al., 2017) estimated for gill nets mesh sizes $(6.9,7.6,8.4,8.9,10.2,11.4 \mathrm{~cm})$. Here, 
the following expression was used for correcting LFD to determine the overall probabilities of capture $\left(P_{t}\right)$ of multi-mesh gillnet fisheries landings (Jayasinghe et al., 2017).

$\left.P_{t}=\left[\sum\left(n_{i} P_{i j}\right)\right] / \max \left[\sum n_{i} P_{i j}\right)\right]$

where, $n_{i}=$ number of net pieces of $i^{\text {th }}$ mesh gillnet; $P_{i j}$ $=$ probability of capture in $i^{\text {th }}$ mesh gillnet in $j^{\text {th }}$ length class; and $\max \left(\Sigma\left(n_{i} P_{i j}\right)\right)=$ maximum value of $\left(\Sigma\left(n_{i} P_{i j}\right)\right)$ estimated. Corrected LFD were used for the estimate of growth parameters using FiSAT II (version 1.2.2) software. Uncorrected LFD were used for the rest of the analyses, such as estimation of mortality rates.

\section{Estimation of growth parameters}

The fish growth was assumed to follow Von Bertanlaffy Growth Function (VBGF). Accordingly, growth constant $(K)$ and asymptotic length $\left(L_{\infty}\right)$ were determined using the VBGF fitted in ELEFAN I routine of FiSAT II (version 1.2.2) (Gayanilo et al., 2005) following the expression of Pauly (1984).

$L_{t}=L_{\infty}\left(1-e^{-K\left(t-t_{0}\right)}\right)$

Where $L_{t}$ is the length of fish at age $t$. The theoretical age at length zero $\left(t_{0}\right)$ was calculated using the empirical formula of Pauly (1979).

$\log _{10}\left(-t_{0}\right)=-0.3922-0.275 \log _{10} L_{\infty}-1.038 \log _{10} K$

The growth performance index $\left(\varphi^{\prime}\right)$ was calculated from the equation below (Pauly and Munro, 1984).

$\varphi^{\prime}=2 \log _{10} L_{\infty}+\log _{10} K$

The index of growth performance $\left(\varphi^{\prime}\right)$, is known to be species specific parameter because it is more or less constant for a family and for a similar taxon (Moreau et al., 1986). As such, this index was used to compare the overall growth of different stocks of 0 . niloticus in different localities. The growth performance indices of 0 . niloticus in 10 reservoirs computed from $L_{\infty}$ and $K$, were compared with those from different localities as reported in Fishbase (Froese and Pauly, 2019) of 0. niloticus. As many $\varphi^{\prime}$ values reported in Fishbase (Froese and Pauly, 2019) were based on standard length (SL), for this comparison, $S L_{\infty}\left(\approx 0.8^{*} T L_{\infty}\right)$ was used. Using a plot of $L n K$ against $L n L_{\infty}$ in different localities (Pauly, 1998), the positions of growth of 10 reservoir populations of the present study in the "growth space" of 0 . niloticus was illustrated.

\section{Estimation of mortality parameters and mean length at first capture}

Total mortality (Z) was computed of 10 population of 0 . niloticus using three independent approaches. As LFD used for the analysis were from multi-mesh gillnet fisheries, it was uncertain whether catch samples in the length classes were unbiased or affected by gillnet selection in the upper end of length-frequency distribution. Hence, the $Z$ estimates using the three approaches were compared to determine the sampling bias has affected the estimates.

a) Length converted catch curve method (Pauly, 1983)

Total mortality ( $Z$ ) was computed using length converted catch curve method as implemented in FiSAT II software. Here, $N / \Delta t$ (where $N=$ number of fish in a given length group and $\Delta t$ is the time needed to grow through the length classes) was plotted against relative age $\left(t-t_{0}\right)$ of length class to estimate $Z$ from descending part of the length-converted catch curve.

\section{b) Beverton and Holt (1956) method}

Beverton and Holt (1956) method of estimation of $Z$ is given by the following formula:

$Z=\frac{K\left(L_{\infty}-L^{\prime}\right)}{\bar{L}-L^{\prime}}$

where $L$ 'is smallest length of fish are fully recruitment to the catch sample. $\bar{L}$ is mean length of fish larger than $L^{\prime}$, and $L_{\infty}$ and $K$ are VBGF parameters. Here $L^{\prime}$ was taken as the length at $50 \%$ retention in the fishing gear, as estimated from a detailed analysis of the ascending part of the length-converted catch curve (see below).

c) Ssentongo and Larkin (1973) method

$Z$ was also calculated from mean length information using the relationship (Ssentongo and Larkin, 1973):

$Z=\frac{(n K)}{\left\{(n+1) \ln \left[\left(L-L^{\prime}\right) /\left(L_{\infty}-\bar{L}\right)\right\}\right.}$

where $L^{\prime}$ and $\bar{L}$ are defined as above and $\mathrm{n}$ is the number of fish used in the estimation of $\bar{L}$.

Natural mortality rate (M) was calculated following empirical relationship using the expression of Pauly (1980):

$\log _{10} M=-0.0066-0.279 \log _{10} L_{\infty}+0.6543 \log _{10} K+$ $0.4634 \log _{10} T$

where $L_{\infty}$ is the asymptotic total length in $\mathrm{cm}, T$ is the mean habitat temperature, and $K$ is the growth coefficient on annual basis. Mean habitat (water) temperature in all 10 reservoirs was considered as 27 ${ }^{\circ} \mathrm{C}$ in the present study, depending on the values reported by Nadarajah (2019). Fishing mortality ( $F$ ) was then calculated using the relationship: $F=Z-M$ (Gulland, 1983). The exploitation level of each reservoir 
population of 0 . niloticus $(E)$ was determined by $E=F / Z$ (Gulland, 1983).

Mean length at first capture $\left(L_{c}\right)$ or length at $50 \%$ selection by fishing gear $\left(L_{50}\right)$ was determined by detailed analysis of the ascending part of the lengthconverted catch curve (Pauly, 1983, 1986).

\section{Relative yield-per-recruit analysis}

Relative yield-per-recruit $\left(Y^{\prime} . R^{-1}\right)$ analysis was carried out incorporating probabilities of capture estimated from detailed analysis of ascending part of length converted catch curve (Pauly and Soriano, 1986; Gayanilo and Pauly, 1997). Here, it was assumed that the selection pattern of the multi-mesh gillnet fishery in 10 reservoirs studied represented selection pattern similar to that of a sigmoid selection curve. This assumption was considered reasonable because LFD were obtained from the gillnet catches of a wide range of mesh sizes. Two levels of exploitation rates were used to determine optimum fishing strategies. $E_{\max }$ is the exploitation rate corresponding to maximum $Y^{\prime} . R^{-1}$ and $E_{0.1}$ is the exploitation rate corresponding to $10 \%$ of marginal increase of $Y^{\prime} . R^{-1}$ at very low level of exploitation (Amarasinghe et al., 2017). Also, $E_{0.5}$ implies the exploitation rate under which the biomass reduces to half of virgin biomass. As there should be a provision for increase of $E$ beyond optimum through increased efficiency of fishing strategies, $E_{0.1}$ was treated as the exploitation level that is necessary to sustain the fishery. This analysis was performed by FiSAT \| (version 1.2.2) software (Gayanilo et al., 2005).

\section{Results}

Length-frequency data corrected for overall gillnet selection in the multi-mesh gillnets using the method presented by Jayasinghe et al. (2017) are shown in Figure 2. Asymptotic total length $\left(L_{\infty}\right)$ of 0 . niloticus populations in 10 reservoirs ranged from $42.8 \mathrm{~cm}$ to $53.4 \mathrm{~cm}$. Also, growth constant $(K)$ ranged from 0.20 $\mathrm{yr}^{-1}$ to $0.49 \mathrm{yr}^{-1}$ (Table 2).

Growth curves of 0 . niloticus superimposed on lengthfrequency distributions corrected for gillnet selectivity in the 10 irrigation reservoirs studied are shown in Figure 3 . The estimated $L_{\infty}$ and $K$ values, fitted well within the plot of "growth space" of 0 . niloticus (Fig. 4), indicating that estimates of growth parameters obtained from ELEFAN I routine of FiSAT II software package were reliable. It further illustrates that the 10 reservoir populations of 0 . niloticus in the present study occupied "growth space" characterising higher $L_{\infty}$ and lower $K$, compared to other populations elsewhere.

Growth performance indices $\left(\varphi^{\prime}\right)$ of 10 reservoir populations of 0 . niloticus are given in Table 2. The $\varphi^{\prime}$ values of 0 . niloticus reported in Fishbase (Froese and Pauly, 2019) ranged from 1.56 to 3.72 (mean: 2.97), indicating that the values of the present study were within the range reported elsewhere. They also substantiate that estimated growth parameters $\left(L_{\infty}\right.$ and $K$ ) in the present study were biologically reasonable.

Total mortality ( $Z$ ) estimated by means of length converted catch curves (Fig. 5), Beverton and Holt (1956) and Ssentongo and Larkin (1973) (Table 2) were closely similar confirming the reliability of estimates. It must be noted that for estimation of $Z$ using lengthconverted catch curves, data points of only the descending part of the curve was considered, and that the data points corresponding to length classes of upper ranges, which did not fall on the straight line were also disregarded. This was done based on the assumption that size classes in the upper tail end of LFD in multi-mesh gillnet fisheries are affected by probabilities of capture lower than unity. Also, the inconsistencies of $Z$ estimates in some reservoirs such as Angamuwa and Rajanganaya (Table 2), maybe due to the effect of gillnet selection on the length frequencies in the upper ends of length classes. As length-converted catch curve is known to be a powerful tool for assessing tropical fish stocks (Pauly, 1983), subsequent analyses were performed using $Z$ values estimated from length converted catch curves. Natural mortality $(M)$, fishing mortality $(F)$ and exploitation rates $(E)$ of 10 reservoir populations of 0 . niloticus are also given in Table 2. Exploitation rates of the 10 populations varied from very low value of 0.14 to high value of 0.76 . Oreochromis niloticus populations in $20 \%$ of the reservoirs are evidently underexploited, $10 \%$ is optimally exploited while the rest of the populations (70\%) are overexploited.

Relative yield-per-recruit $\left(Y^{\prime} . R^{-1}\right)$ values, estimated incorporating probabilities of capture estimated from detailed analysis of ascending part of length converted catch curve (Fig. 6), and presented as a function of exploitation rates $(E)$ were optimised through iteration of series of $L_{c}$ values separately for 10 populations of 0 . niloticus, (Fig. 7). The resulted optimal $L_{c}\left(L_{\text {copt }}\right)$ producing the highest $Y^{\prime} . R^{-1}, E_{\max }$ and $E_{0.1}$ estimated from $Y^{\prime} . R^{-1}$ analysis are given in Table 3 . Also given in Table 3 are length at first capture $\left(L_{c}\right)$ determined from the overall selection characteristics (Fig. 6) for 10 0. niloticus populations and $E_{0.5}$ values of 0 . niloticus in the 10 reservoirs. When the optimal fishing strategies were compared with current levels of exploitation, it was evident that except in Ibbankatuwa and Siyambalangamuwa, $L_{c}$ was much lower than optimal $L_{c}\left(L_{\text {copt }}\right)$ in all other reservoirs. Also, exploitation rates $(E)$ of 0 . niloticus in Ibbankatuwa and Siyambalangamuwa were much lower than $E_{\max }$ and $E_{0.1}$. On the other hand, $E$ values of O. niloticus populations in Angamuwa, Kalawewa, Katiyawa, Rajanganaya and UsgalaSiyambalangamuwa were above the $E_{0.1}$ registering higher $E$ value than $E_{\max }$ in Rajanganaya (Table 3 ). In terms of exploitation rates, 0 . niloticus populations in Balaluwewa, Dewahuwa and Kandalama were 

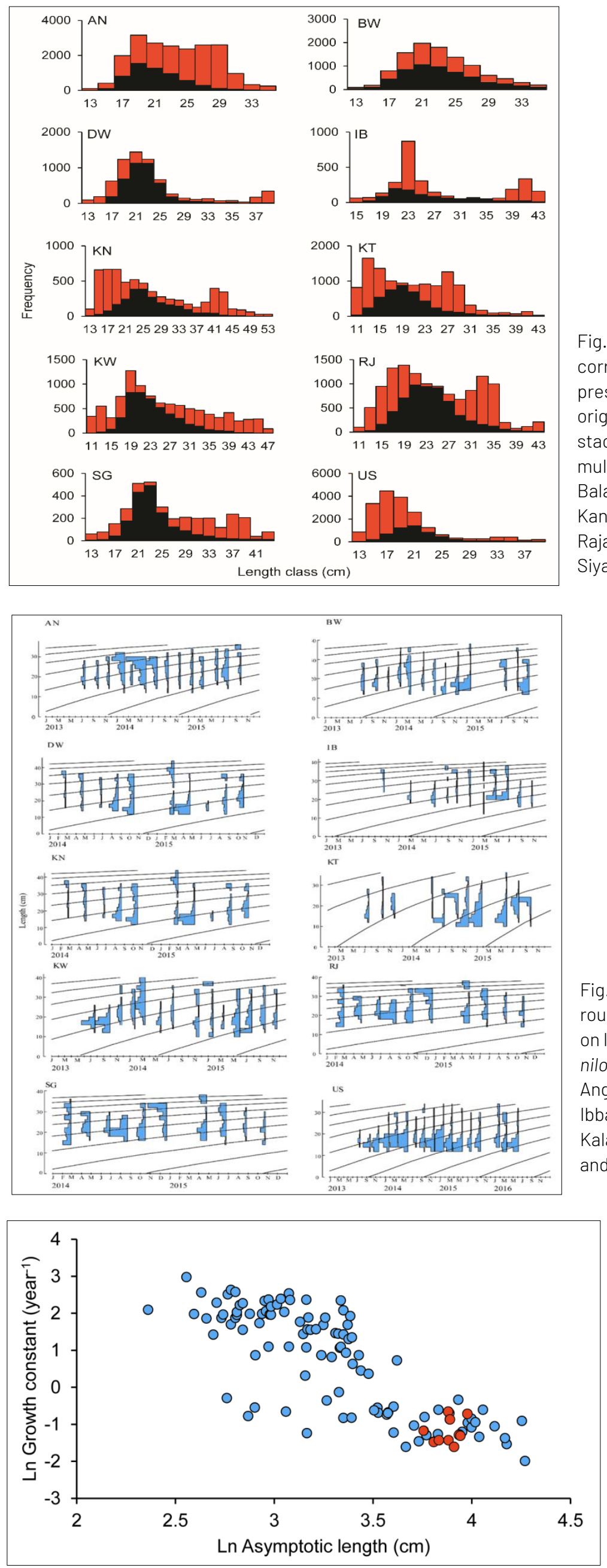

Fig. 2. Length-frequency data of Oreochromis niloticus corrected for gear selection using the method presented by Jayasinghe et al. (2017). Dark columns: original uncorrected length-frequency data; Red stacked columns: Length-frequency data corrected for multi-mesh gillnet selection. An - Angamuwa, Bw Balaluwewa, Dw - Dewahuwa, lb - Ibbankatuwa, Kn Kandalama, Kt - Katiyawa, Kw - Kalawewa, Rj Rajanganaya, Sg - Siyambalangamuwa and Us -Usgala Siyambalangamuwa.

Fig. 3. Growth curves estimated by means of ELEFAN I routine of FiSAT software, which were superimposed on length-frequency distributions of Oreochromis niloticus corrected for gillnet selectivity. An Angamuwa, Bw - Balaluwewa, Dw - Dewahuwa, Ib Ibbankatuwa, Kn - Kandalama, Kt - Katiyawa, Kw Kalawewa, Rj - Rajanganaya, Sg - Siyambalangamuwa and Us -Usgala Siyambalangamuwa.
Fig. 4. Growth space of Oreochromis niloticus as reported in Fishbase (Froese and Pauly, 2019; blue circles). Red circles indicate the estimated $L_{\infty}$ and $K$ values of Oreochromis niloticus of 10 reservoir populations in the present analysis. 
Table 2. Asymptotic length $\left(L_{\infty}\right)$ and growth constant $(K)$ estimated by means of ELEFAN l, theoretical age at length zero (to), growth performance index $\left(\varphi^{\prime}\right)$, total mortality estimated by means of length converted catch curves (Z), Beverton and Holt (1956) $\left(Z_{\mathrm{BH}}\right)$ and Ssentongo and Larkin (1973) (ZSL), natural mortality (M), fishing mortality (F) and exploitation rate (E) of 10 reservoir populations of Oreochromis niloticus.

\begin{tabular}{|c|c|c|c|c|c|c|c|c|c|c|}
\hline Reservoir & $L_{\infty}$ & K & $t_{0}$ & $\varphi^{\prime}$ & Z & $Z_{\mathrm{BH}}$ & $Z_{S L}$ & M & F & E \\
\hline Angamuwa & 42.8 & 0.31 & -0.27 & 2.56 & 1.83 & 1.28 & 1.45 & 0.74 & 1.09 & 0.60 \\
\hline Balaluwewa & 48.5 & 0.24 & -0.20 & 2.56 & 1.34 & 1.08 & 1.13 & 0.6 & 0.74 & 0.55 \\
\hline Dewahuwa & 48.8 & 0.42 & -0.34 & 2.81 & 1.88 & 2.31 & 2.5 & 0.87 & 1.01 & 0.54 \\
\hline Ibbankatuwa & 46.2 & 0.24 & -0.20 & 2.52 & 0.71 & 1.85 & 1.77 & 0.61 & 0.10 & 0.14 \\
\hline Kandalama & 51.3 & 0.28 & -0.53 & 2.67 & 1.25 & 1.09 & 1.23 & 0.66 & 0.59 & 0.47 \\
\hline Katiyawa & 48.4 & 0.52 & -0.22 & 2.89 & 2.87 & 2.77 & 2.99 & 1.00 & 1.87 & 0.65 \\
\hline Kalawewa & 51.5 & 0.27 & -0.54 & 2.66 & 2.06 & 1.34 & 1.51 & 0.64 & 1.42 & 0.69 \\
\hline Rajanganaya & 53.4 & 0.49 & -0.29 & 2.95 & 3.84 & 2.60 & 2.83 & 0.94 & 2.90 & 0.76 \\
\hline Siyambalangamuwa & 45.1 & 0.23 & -0.66 & 2.48 & 0.80 & 0.80 & 0.88 & 0.6 & 0.20 & 0.25 \\
\hline Usgala Siyambalangamuwa & 49.9 & 0.2 & -0.16 & 2.50 & 1.83 & 1.25 & 1.33 & 0.53 & 1.30 & 0.71 \\
\hline
\end{tabular}

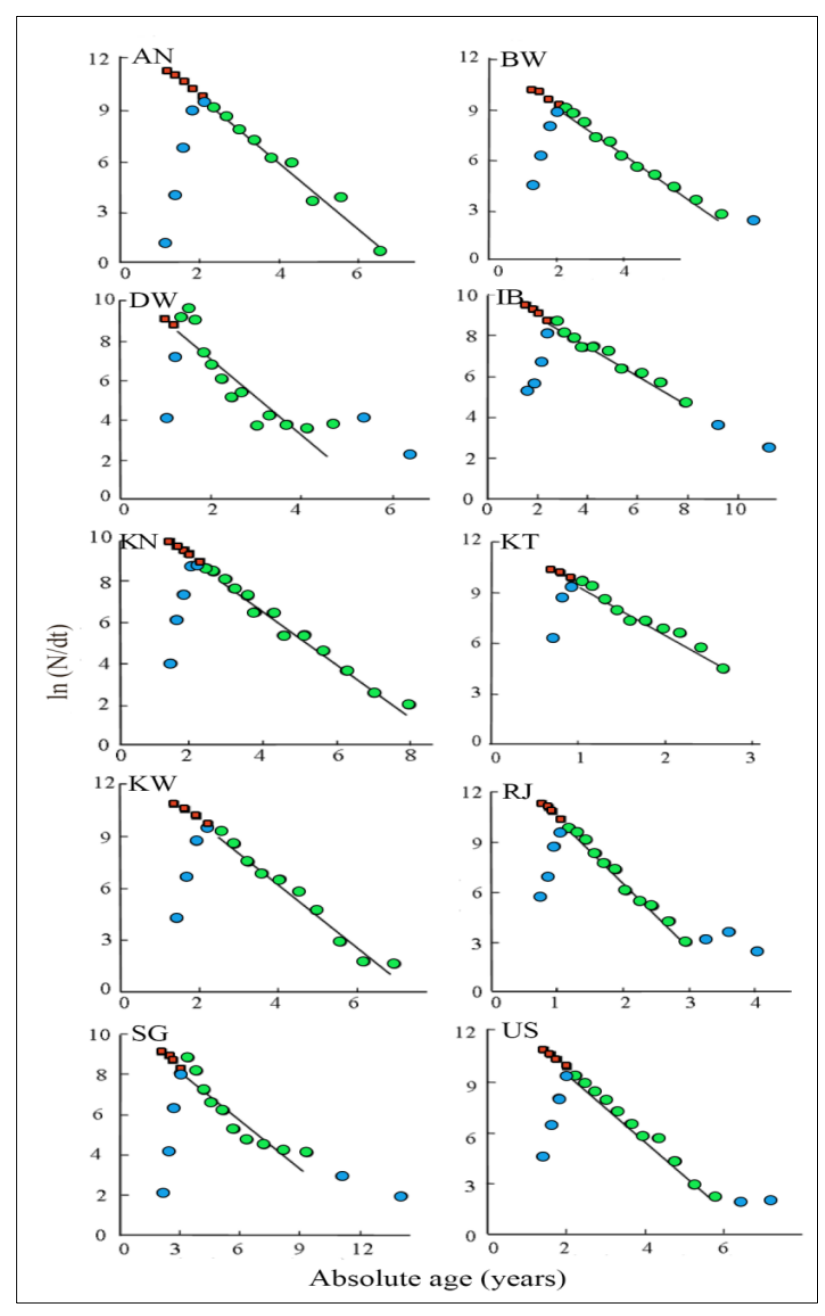

Fig. 5. Length converted catch curves (Pauly, 1983), as implemented in FiSAT II software, of 10 reservoir populations of Oreochromis niloticus. Only red circles were used in the regression analysis to estimate $Z$. See text for explanation of disregarding blue circles in the analysis. Backward projected catch curves to estimate probability of capture through detailed analysis of ascending part of the catch curve are also indicated here. An - Angamuwa, Bw Balaluwewa, Dw - Dewahuwa, lb - Ibbankatuwa, Kn Kandalama, Kt - Katiyawa, Kw - Kalawewa, Rj - Rajanganaya, $\mathrm{Sg}$ - Siyambalangamuwa and Us -Usgala Siyambalangamuwa.

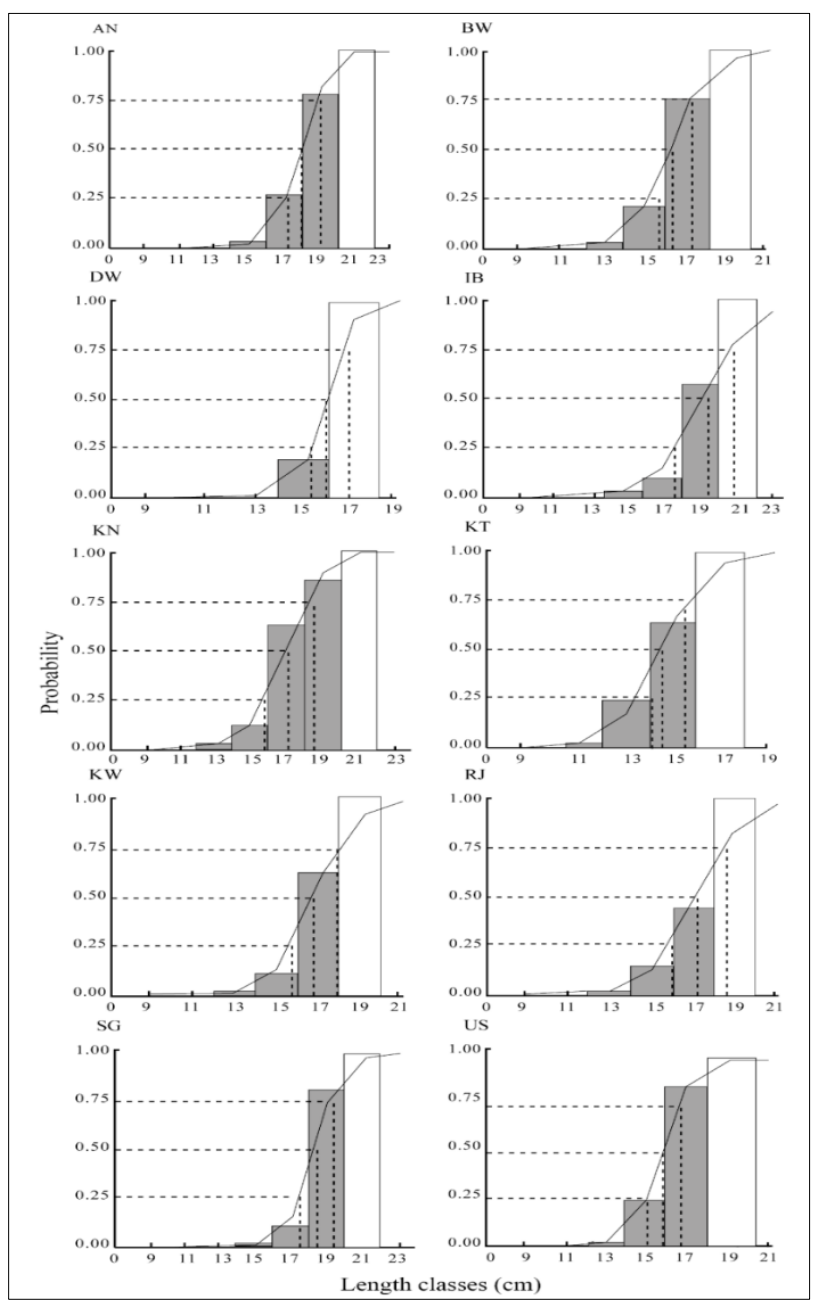

Fig. 6. Selection curves showing probabilities of capture of 10 reservoir populations of Oreochromis niloticus estimated through a detailed analysis of ascending part of length-converted catch curve. An - Angamuwa, Bw Balaluwewa, Dw - Dewahuwa, lb - Ibbankatuwa, Kn Kandalama, Kt - Katiyawa, Kw - Kalawewa, Rj -

Rajanganaya, Sg - Siyambalangamuwa and Us -Usgala Siyambalangamuwa. 
optimally exploited and those in lbbankatuwa and Siyambalangamuwa were under-exploited (Table 3).

Based on a gillnet selectivity study in Sri Lankan reservoirs, Jayasinghe et al. (2017) have derived a relationship between gillnet stretched mesh size ( $X$ in $\mathrm{cm}$ ) and optimal length of 0 . niloticus ( $T L$ in $\mathrm{cm}$ ) as $T L$ $=2.452 X-0.326$. Here, optimal length for a given mesh size of gillnet is the mean value of normal spread of probabilities of capture of length classes. Using this relationship, the gillnet mesh size corresponding to optimal $L_{c}$ of 0 . niloticus in each reservoir population was determined, where mesh size of the commercial gillnet (Table 3 ) ranged from
$7.6 \mathrm{~cm}$ to $10.2 \mathrm{~cm}$. According to the inland fisheries regulations of Sri Lanka (Anon., 1996), the minimum permissible gillnet mesh size in Sri Lankan reservoir fishery is $8.4 \mathrm{~cm}$ stretched mesh. From the present analysis, it is evident that long-term optimal fishing strategies 0 . niloticus can be achieved employing even smaller $(7.6 \mathrm{~cm})$ mesh gillnets in Angamuwa, Ibbankatuwa and Siyambalangamuwa reservoirs. Of the 10 populations studied, 0 . niloticus only in Balaluwewa could be optimally exploited under the existing gillnet mesh regulations, but rest of the reservoir populations require a radical increase of the gillnet mesh size above the legal mesh size to optimise long-term fish yields.

Table 3. Length at first capture $\left(L_{c}\right)$, the optimal $L_{c}\left(L_{\text {dopt }}\right)$ producing the highest $Y^{\prime} . R^{-1}, E_{\max }$ and $E_{0.1}$ estimated from $Y^{\prime} . R^{-1}$ analysis, E0.5 values of Oreochromis niloticus in the 10 reservoirs. Also given here are the estimated optimal stretched mesh sized of gillnets from the relationship of optimal length (i.e., mean value of normal spread of probabilities of capture of length classes) and mesh size (MS est) (Jayasinghe et al., 2017) and corresponding commercial gillnet mesh size (MScomm).

\begin{tabular}{lllllll}
\hline Reservoir & $L_{d}(\mathrm{~cm})$ & $L_{\text {dopt }}(\mathrm{cm})$ & $E_{\max }$ & $E_{0.1}$ & $M_{\text {est }}(\mathrm{cm})$ & $M S_{\text {comm }}(\mathrm{cm})$ \\
\hline Angamuwa & 17.9 & 18.5 & 0.70 & 0.56 & 7.7 & 7.6 \\
Balaluwewa & 16.1 & 20.9 & 0.70 & 0.56 & 8.7 & 8.4 \\
Dewahuwa & 15.8 & 22.6 & 0.70 & 0.57 & 9.3 & 8.9 \\
Ibbankatuwa & 19.3 & 18.3 & 0.65 & 0.52 & 7.6 & 7.6 \\
Kandalama & 16.9 & 21.0 & 0.65 & 0.52 & 8.7 & 8.9 \\
Katiyawa & 14.4 & 21.3 & 0.65 & 0.51 & 8.8 & 8.9 \\
Kalawewa & 16.7 & 21.7 & 0.70 & 0.55 & 9.0 & 8.9 \\
Rajanganaya & 17.3 & 25.8 & 0.70 & 0.57 & 10.7 & 10.2 \\
Siyambalangamuwa & 18.2 & 18.2 & 0.70 & 0.56 & 7.6 & 7.6 \\
Usgala Siyambalangamuwa & 15.8 & 21.0 & 0.70 & 0.55 & 8.7 & 8.4 \\
\hline
\end{tabular}

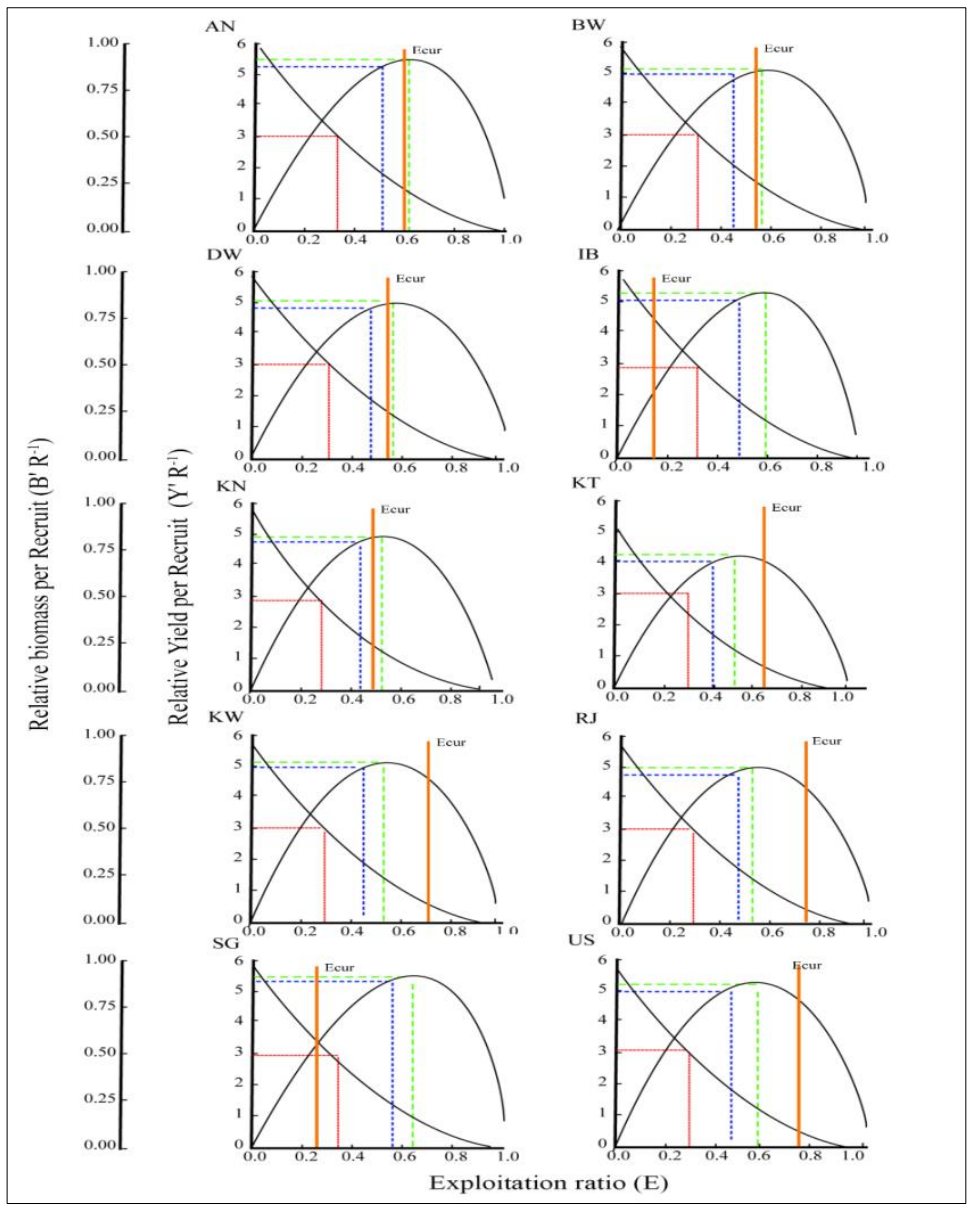

Fig. 7. Relative yield-per-recruit $\left(Y^{\prime} \cdot R^{-1}\right)$ analyses of 10 reservoir populations of Oreochromis niloticus incorporating probabilities of capture estimated from a detailed analysis of ascending part of length converted catch curve (Pauly and Soriano, 1986). Exploitation ratios corresponding to relative biomass-per-recruit $\left(B^{\prime} \cdot R^{-1}\right)$ of 0.5 ( $E_{0.5}$; red dotted lines), to maximum $Y^{\prime} \cdot R^{-1}$ ( $E_{\max }$ i green broken lines) and to $10 \%$ of marginal increase of $Y^{\prime} . R^{-1}$ at very low level of exploitation ( $E_{0.1 ;}$ blue broken lines) are also indicated here. The vertical orange sold lines indicate current $E$ (Ecur) in each reservoir population. An - Angamuwa, Bw - Balaluwewa, Dw Dewahuwa, lb - Ibbankatuwa, Kn - Kandalama, Kt Katiyawa, Kw - Kalawewa, Rj - Rajanganaya, Sg Siyambalangamuwa and Us -Usgala Siyambalangamuwa. 


\section{Discussion}

In Sri Lanka, reservoir fisheries contribute significantly to the rural economy as they are the main sources of animal protein in the diets of rural protein at affordable prices. Oreochromis niloticus accounts for over $70 \%$ of the inland fish production in the country (Amarasinghe and Weerakoon, 2009). As inland fisheries in many parts of Asia are not scientifically managed including Sri Lanka (Amarasinghe and De Silva, 2015), there has been a negative prognosis about the optimal exploitation of inland fishery resources (Welcomme et al., 2010; Youn et al., 2014; Cooke et al., 2016). This notion may be due to uncertainty about the overall applicability of methodologies for assessment of tropical fish stocks and as such, trust is needed to be built and sustained about the methodologies appropriate for assessment of self-sustaining fish stocks in inland waters such as reservoirs. This is particularly due to the reason that noticeable characteristics in many tropical reservoir fisheries such as dominance of highly selective fishing gear such as gillnet, and artisanal nature of the fisheries in which social component is important to be taken into consideration when implementing management strategies (Amarasinghe and De Silva, 1999; Welcomme, 2001) solicit for specific management strategies.

Gillnet fishing, although ubiquitous globally both in marine and inland fisheries, are scientifically disrepute due to negative impacts on biodiversity, through ghost fishing to abandoned gillnets (Takagi et al., 2007), and fisheries bycatch (Wallace et al., 2010). Ghost fishing in abandoned gillnets in fishing grounds is further aggravated due to the reason that in many gillnet fisheries, synthetic non-biodegradable fishing nets are used (Kim et al., 2016). Furthermore, the inaccuracy due to the effect of gillnet selection on the size composition, making the catch samples problematic for employing length-based stock assessment (King, 2007) is needed to be resolved for reliable estimates of growth parameters of fish stocks. In the present study, the accuracy of estimation of growth parameters of 100 . niloticus populations was assured through correction of length-frequency data of gillnet fisheries samples using overall multi-mesh gillnet selection patterns, as performed by Jayasinghe et al. (2017) and Amarasinghe et al. (2017). The estimated growth parameters were shown to be realistic because growth performance indices $\left(\varphi^{\prime}\right)$ of the 10 populations were within the range of the values reported elsewhere. Also, the plot of In $L_{\infty}$ against In $K$ depicting "growth space" of O. niloticus (Pauly, 1998) contained all 10 populations of the present study. De Silva and Senaratne (1988) have shown that as $\varphi^{\prime}$ values of Sri Lankan reservoir populations of Oreochromis mossambicus (Peters, 1852) were higher than those reported from other geographical regions, occupying the extreme of higher $L_{\infty}$ and lower $K$ and emphasised that Sri Lankan reservoir populations were nutritionally advantageous.

TropFishR is a new analytical toolbox for compiling single-species stock assessment methods specifically designed for data-limited fisheries analysis using length-frequency data (Mildenberger et al., 2017). This $R$ package having a powerful algorithm to optimise $L_{\infty}$ and $K$, has been gaining popularity especially because this package includes enhanced versions of all the functions in FiSAT II software. For example, in the small-scale fisheries of three reservoirs in northern Ghana, length-frequency data of three cichlid species were analysed using TropFishR, where length-based stock assessment methods were implemented within a bootstrapping (Abobi et al. (2019). However, in the present analysis, the conventional approach, i.e., FiSAT II software was used.

Once the realistic estimates of growth parameters of fish stocks are available, estimation of mortality rates and optimal fishing strategies is fundamentally relaxed subject to assumptions behind stock assessment methodologies are sufficiently met (King, 2007). LFD of commercial landings were from the fleets of gillnets of stretched mesh sizes ranging from $6.9 \mathrm{~cm}$ to $11.4 \mathrm{~cm}$, so that the overall probability of selection over a wide range of length classes was assumed to be close to unity. Hence, lengthconverted catch curve method, which is known to be a powerful tool for tropical fish stock assessment (Pauly, 1983), could be employed to obtain reliable estimates of $Z$ for the 10 reservoir populations of 0 . niloticus in the present study. The two alternative methods of determination of $Z$ (Beverton and Holt, 1956; Ssentongo and Larkin, 1973) also gave closely similar values corroborating the reliability of the estimates of total mortality in the 10 reservoir populations. Morgan (1985) and Amarasinghe (1987) also have employed these three approaches to authenticate the reliability of total mortality estimates in tropical fish stocks.

Across the 10 reservoir populations of 0 . niloticus, a considerable variation in growth and mortality were evident, which undoubtedly would have long-term effects on the fisheries. From the present study, it was apparent that 0 . niloticus stocks in two reservoirs (Ibbankatuwa and Siyambalangamuwa) were underexploited (Table 2). These two reservoirs are characterised by relatively low phytoplankton biomass, as evident from low chl-a content (Table 1). As such, limnological characteristics appear to be important factors influencing fish production in irrigation reservoirs. Nadarajah et al. (2018) have shown that hydraulic retention time and relative reservoir level fluctuation measured as the ratio of reservoir level amplitude to mean depth had a noticeable influence on the productivity-related water quality parameters. Due to the poor catches, the fishers in Ibbankatuwa reservoir refrain from fishing 
for many days and employ their canoes to take tourists for bird watching. Hence, the increase in the number of fishing boats in these two reservoirs to increase the exploitation rates is not recommended. From the present analysis, it was also evident that 0 . niloticus populations in Balaluwewa, Dewahuwa and Kandalama were optimally exploited. Whereas in Angamuwa, Kalawewa, Katiyawa, Rajanganaya and Usgala-Siyambalangamuwa, $E$ values of 0 . niloticus populations were above the $E_{0.1}$. Although the management recommendations could be based on the present analysis to reduce the exploitation rates through reduced fishing effort. However, in practice, the withdrawal of fishing boats in the artisanal fisheries would be difficult, if not impossible (Purcell and Pomeroy, 2015).

Relative yield-per-recruit $\left(Y^{\prime} . R^{-1}\right)$ analysis is known to be more realistic when probabilities of capture are incorporated (Pauly and Soriano, 1986). As LFD used in the present analysis was from the fleets of mesh sizes ranging from $6.9 \mathrm{~cm}$ to $11.4 \mathrm{~cm}$, it was assumed that the selection pattern of multi-mesh gillnet fishery in the 10 reservoirs represents the selection pattern similar to that of a sigmoid selection curve. This assumption was considered reasonable because the overlapping of bell-shaped selection curves of gillnets in the range of mesh sizes would increase probabilities of capture of length classes in the tailends of gillnet selection curves. The reliability of this analysis could have been further optimised if the overall average selection pattern was determined from the array of fishing mortality that could be computed from length-based virtual population analysis, as attempted by Amarasinghe et al. (2017). However, the two regulatory parameters in the $Y^{\prime} R^{-1}$ analyses estimated in the present study ( $E$ and $L_{c}$ ) were thought to be not compromised, because suboptimal levels of exploitation are preferred as practicable management options for artisanal fisheries in Sri Lankan reservoirs. In fact, in the present analysis, $E_{0.1}$ was treated as the reference point, which would leave some provision for upswing of fishing mortality through behaviour of artisanal fishers to increase the efficiencies of fishing techniques. Amarasinghe and Pitcher (1986) have reported such trends in the fishery of a Sri Lankan reservoir, where fishers beat the water with wooden poles to drive fishes towards gillnets.

As mentioned above, reducing fishing effort in artisanal fisheries is rather tricky due to the direct impacts of such fisheries management options on the livelihoods of fishers. Alternatively, the increase of size at first capture through mesh regulations is a feasible fisheries management option in such situations. In small-scale fisheries in developing countries, livelihood aspects must be considered to be an equal and complementary approach to fisheries management measures (Allison and Ellis, 2001; Purcell and Pomeroy, 2015).
As mentioned above, inland fisheries regulations imposed by the fisheries authorities (Anon., 1996) are aimed at managing the cichlid fishery. As such, the legal mesh size of the gillnet for fisheries in Sri Lankan reservoir fishery ( $8.5 \mathrm{~cm}$ stretched mesh size) is essentially intended for the management of the dominant species, 0 . niloticus in the fishery (Amarasinghe and Weerakoon, 2009). From the present analysis, it was apparent that this legal mesh size of the gillnet for fisheries in Sri Lankan reservoir fishery is inconsistent because in some reservoirs (Angamuwa, Ibbankatuwa and Siyambalangamuwa), long-term fisheries production can be optimised using gillnet mesh sizes of $7.6 \mathrm{~cm}$, while optimal longterm fish yields of 0 . niloticus in Dewahuwa, Kalawewa, Kandalama, Katiyawa and Rajanganaya could be achieved by increasing the permissible gillnet mesh size above the legal mesh size. As such, site-specific management options, which are defined in consultation of resource users are necessary to be implemented in reservoir fisheries of the country. Amarasinghe and De Silva (1999) have also emphasised such an approach for effective management of reservoir fisheries in Sri Lanka.

\section{Conclusion}

The reservoir fishery of Sri Lanka is dominated by the exotic cichlid, 0 . niloticus, making a significant contribution to food production, poverty alleviation and livelihood support. Population dynamics of 0 . niloticus populations of 10 irrigation reservoirs of Sri Lanka investigated by employing length-based stock assessment reproaches indicated that there were differences in growth and mortality parameters across the reservoirs and that predicted optimal fishing strategies were reservoir-specific. In smallscale fisheries such as reservoir fisheries, the sociological importance lies with their contribution to welfare, livelihoods and economic security of the poor (Béné et al., 2010). Hence, social welfare associated with artisanal fisheries must be preserved rather than enforcing management options to maximise the economic rent of fishery resources (Béné et al., 2010). Management recommendations from the present analysis were not directed towards input control, i.e., reduction of fishing effort, but a more feasible management option of regulating gillnet mesh size, which can be materialised through a collective agreement of fishers. Amarasinghe and De Silva (1999) have shown that implementation of such management options would be possible in the Sri Lankan reservoir fishery through fishers' participation in management decision making. From the present analysis, it was also evident that the legal mesh size of the gillnet fisheries in Sri Lankan reservoir fishery (8.5 $\mathrm{cm}$ stretched mesh size), aiming at the management of the cichlid fisheries, dominated by 0 . niloticus is inconsistent. This was because in some reservoirs, long-term fisheries production could be optimised using gillnet mesh sizes of $7.6 \mathrm{~cm}$, while optimal longterm fish yields of 0 . niloticus in other could be 
achieved by increasing the permissible gillnet mesh size above the legal mesh size.

\section{Acknowledgements}

University Grants Commission of Sri Lanka, through the Knowledge Enhancement and Institutional Development Fund, has provided financial assistance to carry out this research. We are thankful to the fishers of 10 reservoirs studied, for their kind cooperation during field data collection. Three anonymous reviewers have given constructive comments, which are highly appreciated. Special thanks are due to Mr. R.P.K.C. Rajapakse for his assistance in preparing figures.

\section{References}

Abobi, S.M., Mildenberger, T.K., Kolding, J., Wolff, M. 2019. Assessing the exploitation status of main fisheries resources in Ghana's reservoirs based on reconstructed catches and a length-based bootstrapping stock assessment method. Lake and Reservoir Management 35:415-434. https://doi.org/10.1080/10402381.2019 .1616340

Ahmad, S.A.S., Bart, A.N., Yang, Y., Rakocy, J.E., Diana, J.S. 2010. The effect of the introduction of Nile tilapia (Oreochromis niloticus, L.) on small indigenous fish species (mola, Amblypharyngodon mola, Hamilton; chela, Chela cachius, Hamilton; punti, Puntius sophore, Hamilton). Aquaculture Research 41:904-912. https://doi.org/10.1111 /j.1365-2109.2009.02372.x

Allison, E.H., Ellis, F. 2001. The livelihoods approach and management of small-scale fisheries. Marine Policy 25:377-388. https://doi.org /10.1016/S0308-597X(01)00023-9

Amarasinghe, U.S. 1987. Status of the fishery of Pimburettewa wewa, a man-made lake in Sri Lanka. Aquaculture and Fisheries Management 18:375-385. https://doi.org/10.1111/j.1365-2109.1987.tb00326.x

Amarasinghe, U.S. 2002. The fishery and population dynamics of Oreochromis mossambicus and Oreochromis niloticus (Osteichthyes, Cichlidae) in a shallow irrigation reservoir in Sri Lanka. Asian Fisheries Science 15:7-20.

Amarasinghe, U.S., De Silva, S.S. 1992. Population dynamics of Oreochromis mossambicus and 0 . niloticus (Cichlidae) in two reservoirs of Sri Lanka. Asian Fisheries Science 5:37-61.

Amarasinghe, U.S., Jayasinghe, R.P.P.K., Moreau, J. 2017. Lengthbased stock assessment of Oreochromis mossambicus and 0 . niloticus (Actinopterygii: Perciformes: Cichlidae) in multi-mesh gillnet fisheries in reservoirs of Sri Lanka. Acta Ichthyologica et Pischatoria 47:265-277. https://doi.org/10.3750/AIEP/02147

Amarasinghe, U.S., Pitcher, T.J. 1986. Assessment of fishing effort in Parakrama Samudra, an ancient man-made lake in Sri Lanka. Fisheries Research 4:271-282. https://doi.org/10.1016/01657836(86)90008-1

Amarasinghe, U.S., Weerakoon, D.E.M. 2009. Present status and future strategies for the management of reservoir fisheries in Sri Lanka. In: Status of reservoir fisheries in five Asian countries, De Silva, S.S., Amarasinghe, U.S. (Eds.), pp. 69-98. NACA Monograph No. 2. Network of Aquaculture Centres in Asia-Pacific, Bangkok, Thailand. http://library.enaca.org/inland/reservoirs08/status_ reservoir_fisheries_asia.pdf

Amarasinghe. U.S., De Silva, S.S. 1999. The Sri Lankan reservoir fishery: a case for introduction of a co-management strategy. Fisheries
Management and Ecology 6:387-399. https://doi.org/10.1046/j.13652400.1999.00170.x

Amarasinghe. U.S., De Silva, S.S. 2015. Fishes and fisheries of Asian inland lacustrine waters. In: Freshwater fisheries ecology, Craig, J.F. (Ed.), pp. 384-403. John Wiley \& Sons, Ltd, Chichester, UK. https://doi.org/10.1002/9781118394380.ch31

Anon. 1996. Inland Fisheries Management Regulations of 1996. Minister of Fisheries and Aquatic Resources Development under section 61 of the Fisheries and Aquatic Resources Act, No. 2 of 1996.

Assefa, W.W., Wondie, A., Enyew, B.G. 2019. Population dynamics and exploitation patterns of Oreochromis niloticus in Lake Tana, northwest Ethiopia. Lakes \& Reservoirs: Science, Policy and Management for Sustainable Use 24:344-353. https://doi.org /10.1111//re.12290

Athukorala, D.A., Amarasinghe, U.S. 2010. Population dynamics of commercially important fish species in two reservoirs of the Walawe river basin, Sri Lanka. Asian Fisheries Science 23:71-90.

Attayde, J.L., Brasil, J., Menescal, R.A. 2011. Impact of introducing Nile tilapia on the fisheries of a tropical reservoir in north-eastern Brazil. Fisheries Management and Ecology 18:437-443. https://doi.org /10.1111/j.1365-2400.2011.00796.x

Béné, C., Hersoug, B., Allison, E.H. 2010. Not by rent alone: analysing the pro-poor functions of small-scale fisheries in developing countries. Development Policy Review 28:325-358. https://doi.org /10.1111/j.1467-7679.2010.00486.x

Beveridge, M.C.M., McAndrew, B.J. 2000. Tilapias: Biology and exploitation. Kluwer Academic Publishers, Springer, Dordrecht. 505 pp. https://doi.org/10.1007/978-94-011-4008-9

Beverton, R.J.H., Holt, S.J. 1956. A review of methods for estimating mortality rates in fish populations with special reference to source of bias in catch sampling. Rapport et Procés-Verbaux des Réunions, Conseil International pour l'Exploration de la Mer 140:67-83.

Blanco, J.A., Narváez Barandica, J.C., Viloria, E.A. 2007. ENSO and the rise and fall of a tilapia fishery in northern Colombia. Fisheries Research 88:100-108. https://doi.org/10.1016/j.fishres.2007.07.015

Brown, C.J., Broadley, A., Adame, M.F., Branch, T.A., Turschwell, M.P., Connolly, R.M. 2019. The assessment of fishery status depends on fish habitats. Fish and Fisheries 20:1-14. https://doi.org/10.1111 Ifaf.12318

Canonico, G.C., Arthington, A., McCrary, J.K., Thieme, M.L. 2005. The effects of introduced tilapias on native biodiversity. Aquatic Conservation: Marine and Freshwater Ecosystems 15:63-483. https://doi.org/10.1002/aqc.699

Cooke, S.J., Allison, E.H., Beard, T.D., Arlinghaus, R., Bartley, D.M., Cowx, I.G., Fuentevilla, C., Leonard, N.J., Lorenzen, K., Lynch, A.J. Nguyen, V.M., Youn, S.J., Taylor, W.W., Welcomme, R.L. 2016. On the sustainability of inland fisheries: Finding a future for the forgotten. Ambio 45:753-764. https://doi.org/10.1007/s13280-016-0787-4

Costa-Pierce, B.A. 2003. Rapid evolution of an established feral tilapia (Oreochromis spp.): the need to incorporate invasion science into regulatory structures. Biological Invasions 5:71-84. https://doi.org /10.1007/978-94-010-0169-4_7

Database on Introductions of Aquatic Species (DIAS). 2019. http://www.fao.org/fishery/dias/en (Accessed 05 June 2019).

De Silva, S.S. 1988. Reservoirs of Sri Lanka and their fisheries. FAO Fisheries Technical Paper No. 298. Food and Agriculture Organization of the United Nations, Rome. 128 pp.

De Silva, S.S., Senaratne, K.A.D.W. 1988. Oreochromis mossambicus is not universally a nuisance species: The Sri Lankan experience. In: The second international symposium on tilapia, Pullin, R.S.V. Bhukaswan, T., Tonguthai, T., Maclean, J.L. (Eds.), pp. 445-450. ICLARM Conference Proceedings 15. Department of Fisheries, 
Bangkok, Thailand and International Centre for Living Aquatic Resources Management, Manila, Philippines.

De Silva, S.S., Subasinghe, R.P., Bartley, D.M., Lowther, A. 2004. Tilapias as alien aquatics in Asia and the Pacific: a review. FAO Fisheries Technical Paper, No. 453. FAO, Rome. 65 pp.

El-Batrawy, O.A., El-Gammal, M.I., Mohamadein, L.I., Darwish, D.H., ElMoselhy, K.M. 2018. Impact assessment of some heavy metals on tilapia fish, Oreochromis niloticus, in Burullus Lake, Egypt. The Journal of Basic and Applied Zoology 79:13 https://doi.org /10.1186/s41936-018-0028-4

Froese, R., Pauly, D. 2019. FishBase. www.fishbase.org (08/2019). (Accessed 10 October 2019).

Gayanilo Jr., F.C., Pauly, D. 1997. FAO-ICLARM fish stock assessment (FiSAT) Reference Manual. FAO Computerized Information Series (Fisheries), 8. FAO, Rome. 262 pp.

Gayanilo, F.C.Jr., Sparre, P., Pauly, D. 2005. FAO-ICLARM Stock Assessment Tools II (FiSAT II). Revised version. User's guide. FAO Computerized Information Series (Fisheries). No. 8. Revised version. FAO, Rome. 168 pp.

Gulland, J.A. 1983. Fish stock assessment. A manual of basic methods. Food and Agriculture, John Wiley \& Sons, Chichester. 223 pp.

Gulland, J.A., Rosenberg, A.A. 1992. A review of length-based approaches to assessing fish stocks. FAO Fisheries Technical Paper No. 323. Rome, FAO. 100 pp.

Hishamunda, N., Bueno, P.B., Ridler, N., Yap, W.G. 2009. Analysis of aquaculture development in Southeast Asia: a policy perspective. FAO Fisheries and Aquaculture Technical Paper. No. 509. FAO, Rome. 69 pp.

Jayasinghe, R.P.P.K., Amarasinghe, U.S., Moreau, J. 2017. Multi-mesh gillnet selectivity of Oreochromis mossambicus and 0 . niloticus (Cichlidae) in the fishery of three large perennial reservoirs in Sri Lanka. Sri Lanka Journal of Aquatic Sciences 22:55-66. doi: https://doi.org/10.4038/sljas.v22i1.7517

Kim, S., Kim, P., Lim, J., An, H., Suuronen, P. 2016. Use of biodegradable driftnets to prevent ghost fishing: physical properties and fishing performance for yellow croaker. Animal Conservation 19:309-319. https://doi.org/10.1111/acv.12256256

King, M. 2007. Fisheries biology, assessment and management, Second edition. Wiley-Blackwell, Oxford. 382 pp. https://doi.org/10.1002 19781118688038

Kolding, J. 1993. Population dynamics and life-history styles of Nile tilapia, Oreochromis niloticus, in Ferguson's Gulf, Lake Turkana, Kenya. Environmental Biology of Fishes 37:25-46. https://doi.org $\underline{/ 10.1007 / B F 00000710}$

Mildenberger, T.K., Taylor, M.H., Wolff, M. 2017. TropFishR: an R package for fisheries analysis with length-frequency data. Methods in Ecology and Evolution 8:1520-1527. https://doi.org/10.1111/2041210X.12791

Ministry of Fisheries and Aquatic Resources Development. 2018. Fisheries statistics, 2017. https://www.fisheriesdept.gov.lk /web/images/pdf/Fisheries_Statistics_2018.pdf (Accessed 20 May 2020).

Moreau J., Bambino, C., Pauly, D. 1986. Indices of overall growth performance of 100 tilapia (Cichlidae) populations. In: The first Asian fisheries forum, Maclean, J.L., Dizon, L.B., Hosillos, L.V. (Eds.), pp. 201-206. Asian Fisheries Society, Manila, Philippines.

Morgan G.R. 1985. Stock assessment of silver pomfret Pampus argenteus in Kuwaiti waters. Journal du Conseil International pour l'Exploration de la Mer 42:3-10. https://doi.org/10.1093 /icesjms/42.1.3
Nadarajah, S. 2019. Limnology and fish yield predictive models in irrigation reservoirs of Sri Lanka. M.Phil. thesis, University of Kelaniya, Sri Lanka. 133 pp.

Nadarajah, S., Wijenayake, W.M.H.K., Gunawardane, N.D.P., Amarasinghe, U.S. 2018. Influence of hydraulic retention time and amplitude of water level fluctuations on water quality in irrigation reservoirs of the Kala Oya river basin, Sri Lanka. Sri Lanka Journal of Aquatic Sciences 23:187-200. https://doi.org/10.4038 /sljas.v23i2.7560

Omar, W.A., Zaghloul, K.H., Abdel-Khalek, A.A., Abo-Hegab, S. 2013. Risk assessment and toxic effects of metal pollution in two cultured and wild fish species from highly degraded aquatic habitats. Archives of Environmental Contamination and Toxicology 65:753764. https://doi.org/10.1007/s00244-013-9935-z

Pauly D., Munro J.L. 1984. Once more on the comparisons of growth in fish and invertebrates. Fishbyte 2(1):21.

Pauly, D. 1979. Theory and management of tropical multispecies stocks: a review, with emphasis on the Southeast Asian demersal fisheries. ICLARM Studies and Reviews No. 1. International Centre for Living Aquatic Resources Management, Manila, Philippines. 350 pp.

Pauly, D. 1980. On the relationships between natural mortality, growth parameters and mean environmental temperature in 175 fish stocks. Journal du Conseil International pour l'Exploration de la Mer 39:175192. https://doi.org/10.1093/icesjms/39.2.175

Pauly, D. 1983. Length-converted catch curves: a powerful tool for fisheries research in the tropics (Part I). Fishbyte 1(2):9-13.

Pauly, D. 1984. Fish population dynamics in tropical waters: a manual for use with programmable calculators. ICLARM Studies and Reviews 8, International Centre for Living Aquatic Resources Management, Manila, Philippines. 325 pp.

Pauly, D. 1986. On improving operation and use of the ELEFAN programs. Part III. Correcting length frequency data for the effect of gear selection and/or incomplete recruitment. Fishbyte 4(2):11-13.

Pauly, D. 1998. Tropical fishes: patterns and propensities. Journal of Fish Biology 53 (Supplement A):1-17. https://doi.org/10.1111/j.10958649.1998.tb01014.x

Pauly, D., Soriano, M.L. 1986. Some practical extensions to Beverton and Holt's relative yield-per-recruit model. In The first Asian fisheries forum, Maclean, J.L., Dizon, L.B., Hosillos, L.V. (Eds.), pp. 491-495. Asian Fisheries Society, Manila, Philippines. 727 pp.

Perschbacher, P.W. 2014. Tilapia: The "Aquatic Chicken" - at last. Journal of Fisheries and Livestock Production 2:120. https://doi.org /10.4172/2332-2608.1000120

Purcell, S.W., Pomeroy, R.S. 2015. Driving small-scale fisheries in developing countries. Frontiers in Marine Science 2:44. https://doi.org/10.3389/fmars.2015.00044

Schofield, P.J., Peterson, M.S., Lowe, M.R., Brown-Peterson, N.J., Slack, W.T. 2011. Survival, growth and reproduction of nonindigenous Nile tilapia, Oreochromis niloticus (Linnaeus 1758). I. Physiological capabilities in various temperatures and salinities. Marine and Freshwater Research 62:1-11. https://doi.org /10.1071/MF10207

Ssentongo, G.W., Larkin, P.A. 1973. Some simple methods of estimating mortality rates of exploited fish populations. Journal of the Fisheries Research Board of Canada 30:695-698. https://doi.org/10.1139/f73$\underline{121}$

Takagi, T., Shimizu, T., Korte, H. 2007. Evaluating the impact of gillnet ghost fishing using a computational analysis of the geometry of fishing gear. ICES Journal of Marine Science 64:517-1524. https://doi.org/10.1093/icesjms/fsm097

Wallace, B.P., Lewison, R.L., McDonald, S.L., McDonald, R.K., Connie Y. Kot, Kelez, S., Bjorkland, R.K., Finkbeiner, E.M., Helmbrecht, S., Larry 
B. Crowder, L.B. 2010. Global patterns of marine turtle bycatch. Conservation Letters 3:131-142. https://doi.org/10.1111/j.1755263X.2010.00105.X

Welcomme, R.L. 2001. Inland fisheries: ecology and management. Fishing News Books, Blackwell Science, Oxford. 358 pp. https://doi.org/10.1002/9780470995693

Welcomme, R.L., Cowx, I.G., Coates, D., Béné, C., Funge-Smith, S., Halls A., Lorenzen, K. 2010. Inland capture fisheries. Philosophical Transactions of the Royal Society B 365:2881-2896. https://doi.org /10.1098/rstb.2010.0168

Youn, S.J., Taylor, W.W., Lynch, A.J., Cowx, I.G., Beard, T.D. Jr, Bartley, D., Wu, F. 2014. Inland capture fishery contributions to global food security and threats to their future. Global Food Security 3:42-148. https://doi.org/10.1016/j.gfs.2014.09.005 